\title{
Non-thermal Plasma for VOC Treatment in Flue Gases
}

\author{
Janis Ikaunieks ${ }^{1}$, Liga Mezmale ${ }^{2}$, Aivars Zandeckis ${ }^{3}$, Jelena Pubule $^{4}$, Andra Blumberga $^{5}$, Ivars Veidenbergs ${ }^{6}$, \\ ${ }^{1-6}$ Institute of Energy Systems and Environment, Riga Technical University
}

\begin{abstract}
The paper discusses non-thermal plasmas, their generation and characteristics, formation mechanisms of ozone and the treatment of volatile organic compounds (VOCs). In the experimental part, undecane $\left(\mathrm{C}_{11} \mathrm{H}_{24}\right.$ as model VOCs) was treated with assistance of low temperature plasma at an atmospheric pressure which was generated in the so-called stack reactor. The gas composition was $13 \%$ of oxygen in nitrogen with impurities of carbon dioxide, carbon monoxide and undecane. The formation of by-products, as well as the removal efficiency, were investigated.
\end{abstract}

Keywords - Non-thermal plasma, dielectric barrier discharge, VOC treatment

\section{INTRODUCTION}

Recently, the increasing number of scientists stress the negative impact of volatile organic compounds (VOCs) on human health and environment. VOCs in the atmosphere are participating in photochemical smog formation reactions. They are also known to be toxic and cancerogenic [1,2]. VOC are classified in two groups: methane and non methane volatile organic compounds (NMVOC). Methane is a known greenhouse gas, but some of NMVOC are also involved in global warming mechanisms [1].

In recent years, plasma technologies play a growing role in environmental protection. These technologies have still undiscovered potential to reduce emissions efficiently and at a reasonable cost. Low temperature plasma generates a variety of radicals and other active species, such as ozone. These species are responsible for the oxidation of hazardous compounds in flue gases.

Plasma is a partly or fully ionized gas, where the total amount of positive and negative charges is equal, the so-called quasi neutrality. It is the most common state of matter in the Universe. About $99 \%$ of visible mater in the Universe consists of plasma. On the Earth, one of the most common plasma sources are lightnings [3].

In 1777 Georg Christoph Lichtenberg started to explore electrical discharges in isolation, where he observed electrical trees. From that point on, different studies were made, but a turning point was when Werner von Siemens discovered the dielectric barrier discharges (DBDs). They were used to generate ozone, mainly for water treatment. Nowadays, still DBDs are used in many environmental applications [4].

By the different properties, plasmas can be divided in two parts - thermal and non-thermal plasmas (NTP). In thermal plasma, electrons and ions have equal energy - the plasma is in equilibrium. Electron temperature, as a measure of energy in NTP, can range up to $1-20 \mathrm{eV}(1 \mathrm{eV} \approx 11600 \mathrm{~K})$. While ions and neutral species remain near room temperature $(0.025 \mathrm{eV} \approx$ $293 \mathrm{~K}$ ), the plasma is not in equilibrium [5]. This is due to the fact, that the energy is mainly transferred to the light electrons. Nevertheless, the exact differentiation between thermal and non-thermal plasmas depends on the classification. This contribution discusses only NTP generation and treatment.

NTP can be used in many different ways, but for environmental protection NTP is mainly used for flue gas treatment, particulate matter treatment, odour purification, water cleaning, etc. [6]. Since plasma technologies have an undiscovered potential, they are a promising alternative tool for environmental protection, economically and ecologically [6].

By supplying plasma reactors with external energy, e.g. by applying an electric field, the dissipation of atoms into ions and electrons can be achieved. Free electrons can then interact with other ions and neutral species. There are two types of collisions [3]:

- elastic collisions do not change the internal energy of neutral matter, but increases their kinetic energy;

- inelastic collisions are collisions with high energy. They change the structure of a neutral matter, which results in the formation of active radicals and ions.

An applied electrical field accelerates the electrons, therefore they can collide with molecules and neutral species, creating excited molecules which can then create active species like $\mathrm{O}, \mathrm{O}_{3}, \mathrm{~N}, \mathrm{OH}$, etc.

Reactions and other processes occur quite fast. The basic processes, like ionization, excitation and dissociation, take part in $10^{-15} \mathrm{~s}$. Therefore, we can see that gas residence time in plasma plays a minor role [7].

To obtain DBD, it is necessary to have at least one dielectric layer between the electrodes (see Fig. 1). The discharges are generated by applying an AC voltage of several $\mathrm{kV}$ and frequency between $50 \mathrm{~Hz}$ and $1 \mathrm{MHz}$. At atmospheric pressure in the air, the DBD consists of so-called microdischarges (MDs). Their appearance follows three main steps [8]:

- pre-discharge phase - negative electrons and ions accumulate in front of anode, according to polarity. The duration of this phase is at least $10^{-6} \mathrm{~s}$, until a high local electrical field is accumulated. With reaching a critical point, a MD starts from the surface of the anode;

- propagation phase - more and more positive charges start to accumulate. In front of the region of positive charges, more and more new electrons and ions are created, due to 
the electric field distortion. The duration of this phase is approximately $1-2 \cdot 10^{-9} \mathrm{~s}$

- destruction phase - the MD crossed the gap between the electrodes. Positive charges accumulate on the dielectric layer, compensating the external electrical field. As a result, the MD decays.

This propagation mechanism is called a streamer mechanism. With changing of the polarity, the MDs take place according the same mechanism in the opposite direction. MDs also can be characterized as short-lived transient glow discharges. The radius of a MD channel is approximately 0.1 $\mathrm{mm}$. The radius and the transferred charges do not depend on the applied voltage. With increased voltage, more MDs appear. Therefore, it is possible to investigate upscaleable reactors in a laboratory environment $[4,8,9]$.

DBDs are considered to be one of most popular reactor type for flue gas treatment.
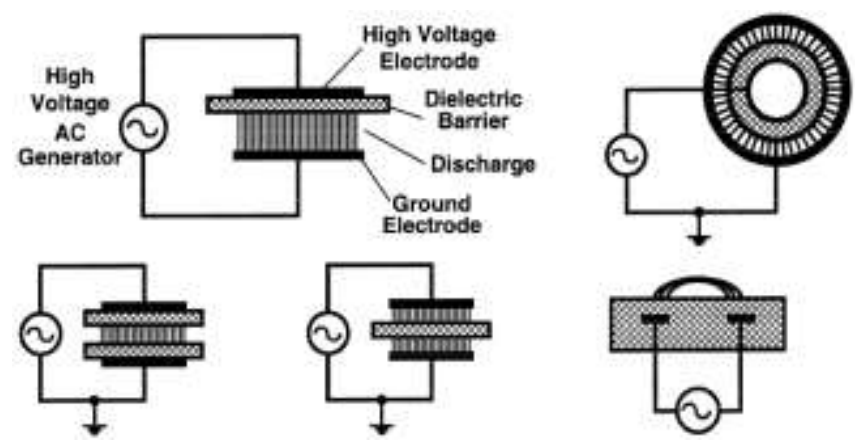

Fig. 1. DBD reactor types [4].

The biggest DBD advantages are that they do not need vacuum, they operate in atmospheric pressure, they do not need complicated power source and they are easy to build up. DBDs are usually used [8]:

- for ozone generation;

- in luminescent lamps ;

- in plasma displays;

- for air treatment;

- in $\mathrm{CO}_{2}$ lasers;

- surface treatment.

\section{OZONE PRODUCTION AND VOC TREATMENT METHODS}

As already stated, non-thermal plasmas produce active species, such as radicals and ozone, which enable the possibilities of the plasma chemistry. In this paper, the main attention is on the production of ozone, as the main active compound. This is due to its relative long lifetime of about 20 minutes and the fact that ozone is known to be one of the best oxidants. As ozone starts decomposing at $100^{\circ} \mathrm{C}$, the flue gas temperature should be below that level to obtain the best results. At higher temperatures, ozone appears only in a transient form and, therefore, other species play a more important role. The DBD is suitable for this application. Ozone production is a two-stage process. It starts with oxygen molecule dissociation [10]:

$$
e+\mathrm{O}_{2} \rightarrow 2 \mathrm{O}+e
$$

At the second stage, atomic oxygen reacts with oxygen molecule, creating ozone [10]:

$$
\mathrm{O}+\mathrm{O}_{2}+\mathrm{M} \rightarrow \mathrm{O}_{3}+\mathrm{M}
$$

where $\mathrm{M}$ is a third body.

Two main reactions 1-2 take part only in presence of oxygen. Beside the above mentioned main reactions, there are approximately 100 possible reaction path ways for ozone production and decomposition [10].

In air, ozone generation is a more complex process than in pure oxygen. Excited nitrogen species in air take a major part in those processes, as well as in forming nitrogen oxides, like $\mathrm{NO}, \mathrm{NO}_{2}, \mathrm{NO}_{3}, \mathrm{~N}_{2} \mathrm{O}_{5} \mathrm{~N}_{2} \mathrm{O}$ [11]. Nitrous oxide $\mathrm{N}_{2} \mathrm{O}$ is the initial oxide formed within $100 \mathrm{~ns}$ after the initiation of microdischarge [11]. The main reaction leading to $\mathrm{N}_{2} \mathrm{O}$ formation is involving metastable excited $\mathrm{N}_{2}$ molecule:

$$
\mathrm{N}_{2}+\mathrm{O}_{2} \rightarrow \mathrm{N}_{2} \mathrm{O}+\mathrm{O}
$$

The formation of nitrogen oxides in ozone production has its disadvantages:

1. Nitrogen oxides are undesirable in atmosphere because they form smog, participate in ozone depletion, and $\mathrm{N}_{2} \mathrm{O}$ is a greenhouse gas with global warming potential 298 [12];

2. Nitrogen oxide formation consumes a lot of energy, decreasing plasma efficiency, but in air it cannot be avoided [6].

About a half of the produced ozone in air is formed in reactions with nitrogen oxides [8]. As it is mentioned in the literature, the more power is fed to reactor, the more ozone and nitrogen oxides are produced.

There are already known methods for VOC treatment as adsorption, absorption, thermal oxidation, etc. Recently, using non-thermal plasmas for VOC treatment has been proven to be economically and ecologically profitable.

Rafflenbeul presented in his works [13] a comparison of different technologies for waste air purification process $\left(\left(50,000 \mathrm{~m}^{3} \mathrm{~N} / \mathrm{h}\right)\right.$ for $\left.<100 \mathrm{mg} \mathrm{VOC} / \mathrm{m}^{3}\right)$ in the flavor processing (see Fig. 2).

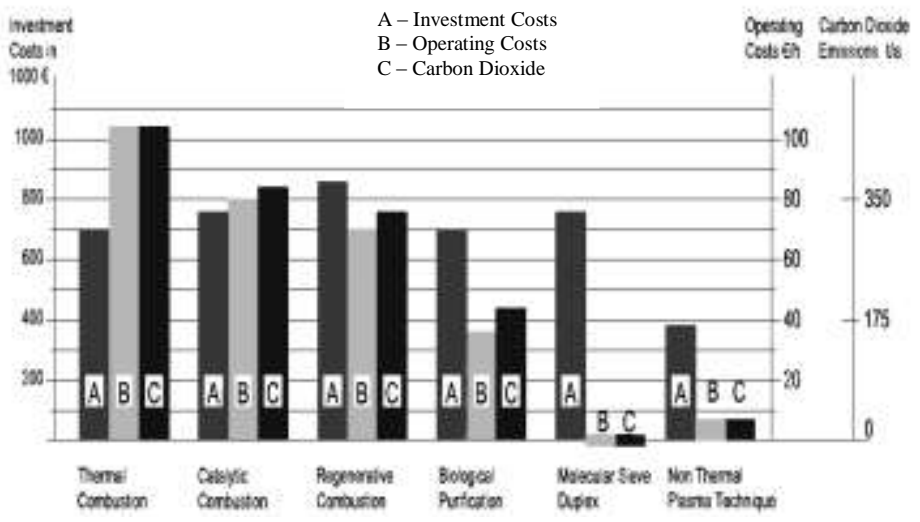

Fig. 2. Investment and running cost comparison of waste air purification processes $\left(50,000 \mathrm{~m}^{3} \mathrm{~N} / \mathrm{h}\right)$ for $<100 \mathrm{mg} \mathrm{VOC} / \mathrm{m}^{3}$ in the flavor processing industry [13]. 
Figure 2 shows that non thermal plasma is competitive. Nevertheless, one should take into account, that investment and operational costs are usually higher for flue gas treatment. In order identify all aspects, cost benefit analysis has to be done. Not all benefits can be described in monetary terms. The main benefits of plasma technologies usually are avoided payments for air pollution, avoided external costs and health benefits. The advantages of NTP for flue gas treatment are [14]:

- VOC are oxidized to less noxious gases like $\mathrm{CO}_{2}$ and $\mathrm{H}_{2} \mathrm{O}$;

- The energy consumption of the plasma technology is less than for thermal oxidation units. There is no need for fan in NTP, because pressure drop in stack is lower, comparing with adsorption and absorption; therefore, total energy costs are less;

- NTP works at atmospheric pressure and room temperature;

- NTP can be combined with other technologies (e.g. adsorbance);
- plasma technologies can simultaneously treat organic and inorganic pollutants.

Although complete VOC oxidation in NTP form nonharmless substances often alkane and ozone reactions could lead to formation of many by-products. For example, $n$ decane oxidation involves isomeric decanones, primary alcohols, secondary isomeric decanols, esters, c-alkylbutyrolactones, C1-C9 monocarboxylic acids, ketocarboxylic acids, dicarboxylic acids and hydroxy acids [15].

\section{DESCRIPTION OF EXPERIMENTAL PART AND DEVICES}

The aim of the experiments was to research the oxidation of a sample hydrocarbon, namely undecane in DBD plasma.

The experimental part consisted of three main parts:

1. Ozone concentration measurements in DBD without undecane

2. Investigation of by-product formation

3. Ozone and $\mathrm{N}_{2} \mathrm{O}$ concentration measurements with undecane

The experimental setup is shown in Figure 3.

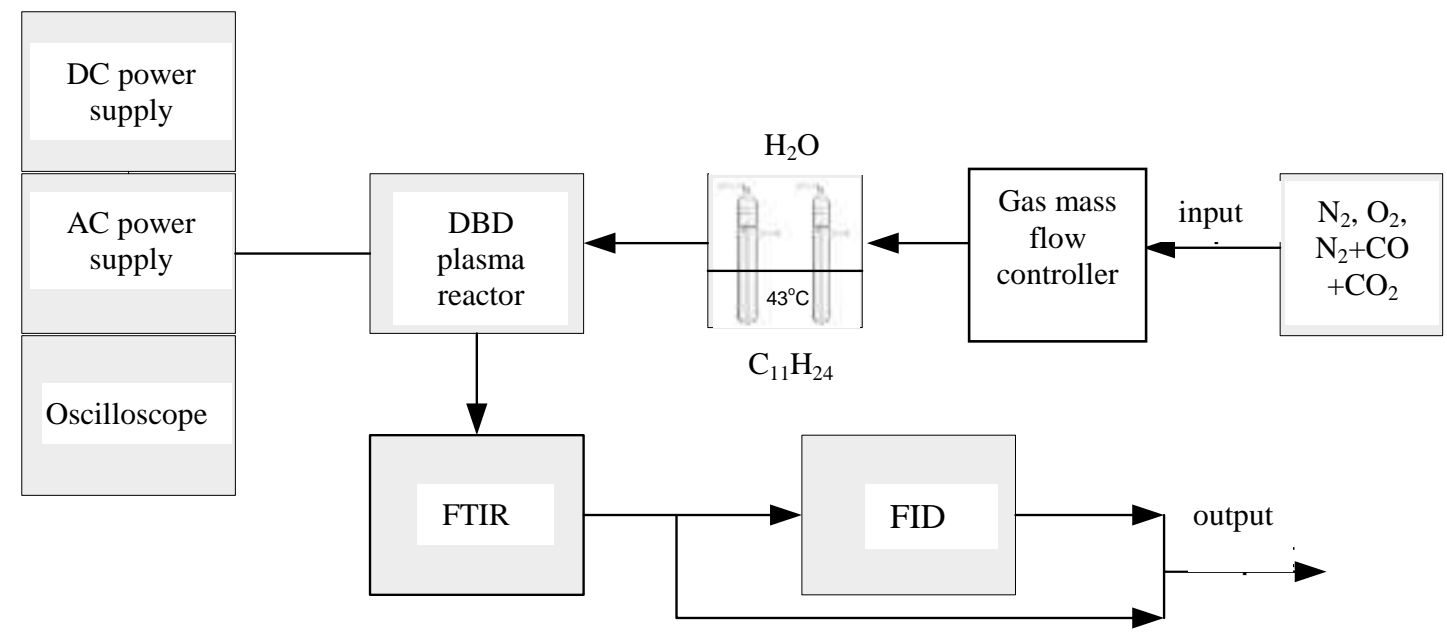

Fig. 3. Scheme of the experimental setup.

It consisted of the gas mixing equipment, the plasma device, its power supply and the gas analytics.

The gas composition was implemented by adjusting the gas flow of nitrogen, oxygen, carbon monoxide and carbon dioxide by mass flow controllers. This way, a gas composition of $13 \%$ oxygen, $200 \mathrm{ppm}$ of $\mathrm{CO}$ and $1000 \mathrm{ppm}$ of $\mathrm{CO}_{2}$ at a flow of $900 \mathrm{~L} / \mathrm{h}$ could be achieved. The concentration of 200 ppm of undecane and $1 \%$ of water were achieved by gas bubblers. The plasma device was a DBD, build up in a stack reactor design. As a power supply, a resonance power supply provided by the Western Pomeranian University of Technology Szczecin was used. It was driven by a DC power supply (EA-PS 3150-04B). The details of this power supply were already discussed in by Kalisiak et. al. [16]. An oscilloscope (Tektronix DPO 4104) with voltage probe was used for direct measurements of current and voltage. While the voltage was measured with a high voltage probe
(Tektronix P6015A), the current was measured with a resistor $(50 \Omega)$. The multiplication of both values equals the power.

Gas analytics consisted of Fourier transform infrared spectroscopy - FTIR (Gasmet CR2000 and Alpha Bruker with long path gas cell $4.8 \mathrm{~m}$ ) and Flame ionization detector - FID (Testa 2010T) for continuous gas measurements.

The maximum input power was limited to $100 \mathrm{~W}$, because this would be suitable to the average household heating system VOC treatment. The reactor contained of HV, ground mesh electrodes and dielectric layers of mica between them. The discharges appear not only in volume, but also on the surface of dielectrics. The use of a stack reactor has already been studied in [5]. 


\section{METHODS}

Tests were carried out in three parts. The first part was to observe ozone production in plasma DBD reactor without undecane. The aim of first experiment part was to precise amount of ozone and nitrogen oxides. The applied power was raised from $10 \mathrm{~W}$ up to $100 \mathrm{~W}$ in $5 \mathrm{~W}$ steps. Data used for ozone and $\mathrm{N}_{2} \mathrm{O}$ concentration was an average value. This was necessary since the concentration was fluctuating.

The second part was to observe the precise amount of ozone and $\mathrm{N}_{2} \mathrm{O}$ in reactor with undecane. Methodology of experiment was as in the first part.

The third part was to investigate by-product formation from undecane oxidation. It is clear that although there was an excess of ozone a lot of by-products were formed. Byproducts were identified with the FTIR "Alpha" of Bruker.

\section{RESUlts}

In the first experiments, only ozone and $\mathrm{N}_{2} \mathrm{O}$ were observed as by-products. Figure 4 represents ozone and $\mathrm{N}_{2} \mathrm{O}$ dependence on specific energy density (SED). Meanwhile, $\mathrm{CO}, \mathrm{CO}_{2}$ and $\mathrm{H}_{2} \mathrm{O}$ concentration did not change at all. That means that there were no by-products produced. At the power of $20 \mathrm{~W}$, ozone could first be detected $(0.87 \mathrm{ppm})$. That means that critical breakdown voltage was achieved just before that point. In this case, voltage was $2.3 \mathrm{kV}$ and frequency was about $900 \mathrm{~Hz}$, but $\mathrm{N}_{2} \mathrm{O}$ concentration first was observed at 30 W $(0.58 \mathrm{ppm})$, which corresponds to $2.8 \mathrm{kV}$ and approximately the same frequency. At that time, the ozone concentration in gas was already $25.95 \mathrm{ppm}$.

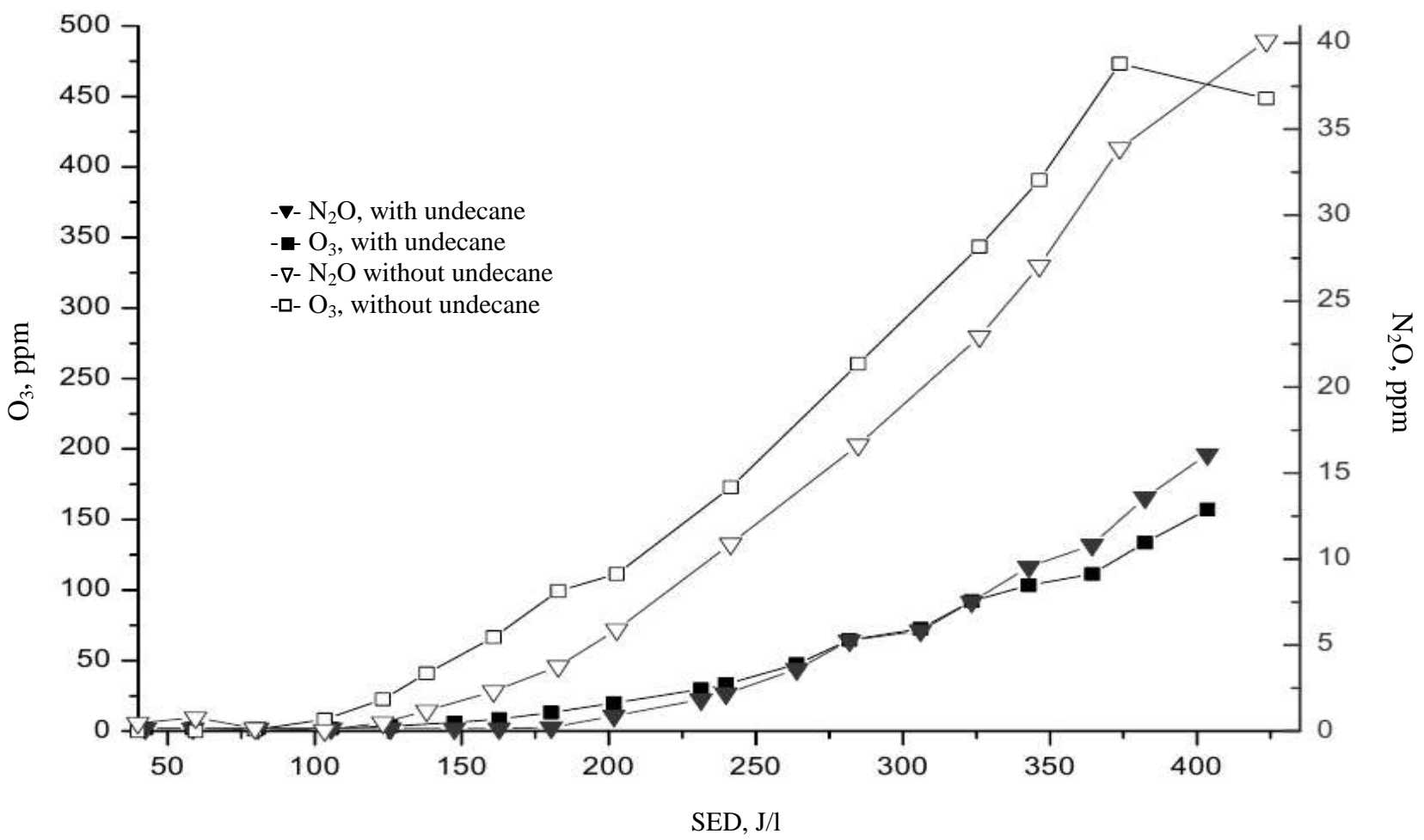

Fig. 4. Ozone and $\mathrm{N}_{2} \mathrm{O}$ concentration depending on the specific energy density with and without undecane.

In Figure 4 Ozone and $\mathrm{N}_{2} \mathrm{O}$ concentration is raising with the increasing power. Without undecane, the function is exponential - at the beginning there is no ozone produced and then suddenly it increases drastically. The difference with and without undecane can be observed.

In second case ozone concentration was first observed at 30 W $(2.29 \mathrm{ppm})$. Next to that, an increase of $\mathrm{CO}$ and $\mathrm{CO}_{2}$ concentration could be detected. Therefore, the conclusion can be drawn, that undecane was reacting with the reactive species in the plasma. Besides that, the $\mathrm{N}_{2} \mathrm{O}$ concentration with and without undecane in the reactor was completely different (see Fig. 4). As stated in the introduction, ozone and $\mathrm{N}_{2} \mathrm{O}$ have similar reaction paths. That means that $\mathrm{N}_{2} \mathrm{O}$ concentration with and without undecane should not change, because the power input is the same.
The first proposed explanation could be that oxygen atoms which produce $\mathrm{N}_{2} \mathrm{O}$ are much more consumed in reactions with undecane. It is important to notice that almost all volume consists of nitrogen and oxygen, but undecane is only 200 $\mathrm{ppm}$. The probability that oxygen will collide with undecane is much smaller, rather than the probability that it will happen with nitrogen atoms.

The second proposed explanation could be that undecane directly reacts with plasma. Then it would change all processes comparing with first experiment. This explanation could be the most logical one.

Figure 5 shows comparison of gas FTIR spectra with undecane when power is $10 \mathrm{~W}$ and $103 \mathrm{~W}$. As it was mentioned before, discharges start to develop when power fed to reactor is about $20 \mathrm{~W}$. It means that at $10 \mathrm{~W}$ spectra there 
are no reactions, but, on the other hand, at $103 \mathrm{~W}$ spectra, there are a lot of reactions

Theoretically, gas after plasma reactor should contain not only undecane, but also other hydrocarbons, because of the incomplete oxidation. By comparing reference spectra, it was concluded that $\mathrm{n}$-alkanes in FTIR spectrum look very similar. Therefore, it is hard to distinguish which n-alkanes are in the gas.

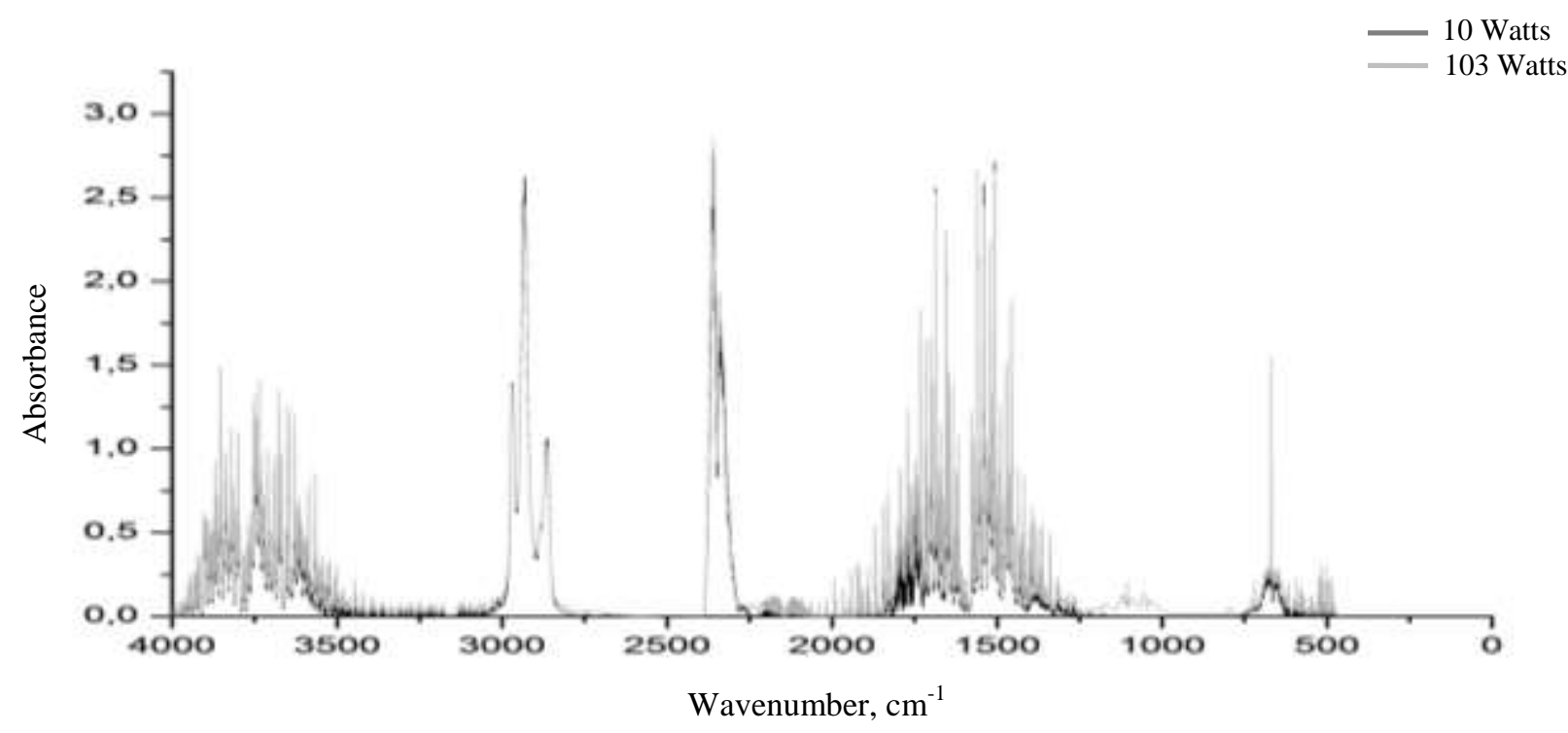

Fig. 5. FTIR spectra of gases with undecane in DBD plasma treatment with power $10 \mathrm{~W}$ and $103 \mathrm{~W}$.

Although it is possible to identify the main substances, there might be others which cannot be detected, due to the used method. The bands of water cover big part of the spectrum and, therefore, could mask other substances as well. In general, the spectra are similar, but there are minor changes. After data processing, it was concluded that these minor changes are ozone and formic acid at $1100 \mathrm{~cm}^{-1}$. At $2200 \mathrm{~cm}^{-1} \mathrm{~N}_{2} \mathrm{O}$ and $\mathrm{CO}_{2}$ appeared as predicted. With a concentration of up to $46 \mathrm{ppm}$, formic acid made a major by-product.

As predicted, the undecane destruction and removal efficiency (DRE) will not be very high, because of the low energy amount fed to reactor. The key solution how to increase DRE was to increase the interaction time between undecane and ozone, because in the output there was still about 200 ppm ozone. $\mathrm{O}_{3}$ is the most important oxidizer in VOC treatment in non-thermal plasma. After the reactor, DRE was only $27 \%$ (see Fig. 7). The increasing energy raises ozone in output and decreases the total amount of undecane, but the undecane removal occurs more slowly than production of ozone.

It means that there is no reason to improve capacity of the power supply, but it would be necessary to raise efficiency. The suggested solution is to use adsorbents after plasma DBD reactor. Adsorbents would increase the interaction time between undecane and ozone, and it could significantly improve DRE and by-product formation.

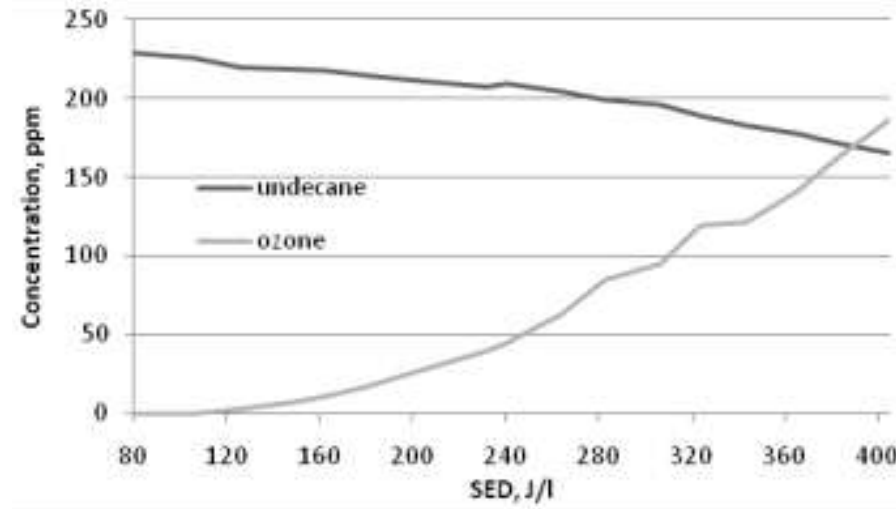

Fig. 6. Ozone and undecane concentration, depending on specific energy density.

The concentration of gases was measured in the reactors exhaust. At the end, 27\% undecane removal efficiency was achieved, and there was still about 200 ppm ozone, which did not have enough time to react with undecane.

The highest destruction and removal efficiency was reached at $101 \mathrm{~W}$, which corresponds to $404 \mathrm{~J} / \mathrm{l}$ and 112 $\mathrm{Wh} / \mathrm{m}^{3}$, and it was $27 \%$. Figure 5 shows that DRE is raising by increasing energy fed to plasma reactor. 


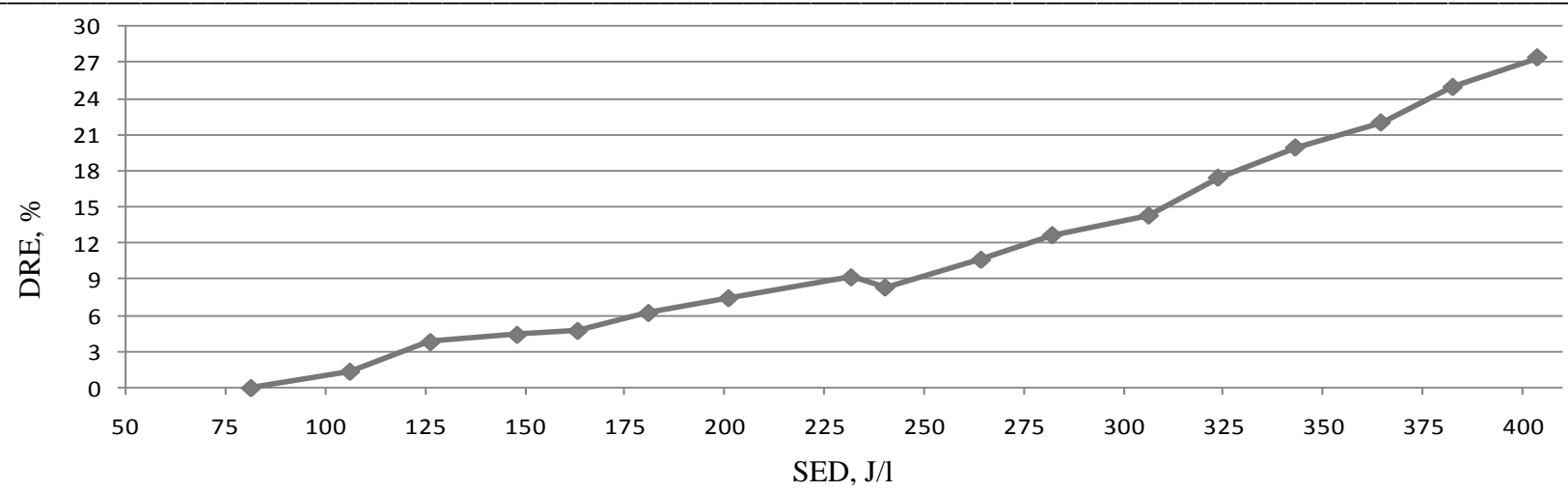

Fig. 7. Destruction and removal efficiency depending on specific energy density

\section{CONCLUSions}

In this paper, the introduction to non-thermal plasma and undecane (as one of the VOC's) treatment with dielectric barrier discharge have been analysed. The following conclusions from this paper can be drawn:

1. As VOC abatement produces high concentration of byproducts, it is necessary either to use catalytic surfaces or adsorbents to decrease the by-product formation and to increase VOC removal. Ozone and undecane reaction time has to be improved to achieve the higher removal efficiency.

2. When producing ozone in air, nitrogen oxide formation cannot be avoided. The increasing power raises the nitrogen oxide concentration and, when reaching a certain level, ozone production decreases till it stops.

3. Nitrous oxide forms differently with or without undecane in the reactor, and it was the only by-product from nitrogen oxides observed in the DBD.

4. It is necessary to use more complex methods for byproduct observation, because in FTIR spectrum the bands of water cover big part of the spectrum and, therefore, could mask other substances as well.

\section{ACKNOWLEDGEMENT}

The authors would like to thank Leibniz-Institute for Plasma Science and Technology and especially Dr. Ronny Brandenburg, Dipl. Ing. Alexander Schwock and Dipl. Phys. Helge Grosch for hosting this research and making the data available. The study was part-financed by the European Regional Development Fund, the Baltic Sea Region programme 2007-2013 (project No 033, "Dissemination and Fostering of Plasma Based Technological Innovation for Environment Protection in the Baltic Sea Region", PlasTEP).

\section{REFERENCES}

1. Sobacchi, M.G., Saveliev, A.V., Fridman, A.A., Gutsol, A.F. Kennedy, L.A. Experimental Assessment of Pulsed Corona Discharge for Treatment of VOC Emissions. Plasma Chemistry and Plasma Processing, 2003, Vol. 23, No. 2, 347.-370.

2. Kḷaviṇš, M. Vides piesārṇojums un tā iedarbība. LU akadēmiskais apgāds 2009, 61-97

3. Tendero, C., Tixier, C., Tristant, P, et. al. Atmospheric pressure plasmas: A review // Spectrochimica Acta Part B 61, 2006.
4. Kogelschatz, U. Eliasson, B. Egli W. From ozone generators to flat television screens: history and future potential of dielectric-barrier discharges // Pure Appl. Chem., Vol 71, No 10, 1999

5. Müller, S., Zahn, R.-J. Air Pollution Control by Non-Thermal Plasma. Contrib. Plasma Phys. 47. 2007, No. 7, 520-529

6. Konelschatz, U. Eliasson B. Egli W. Dielectric-Barrier Discharges Principle and Applications Colloque C4, Supplement au Journal de Physique I11 d'octobre 1997

7. Kim, H. H. Nonthermal Plasma Processing for Air-PollutionControl: A Historical Review, Current Issues, and Future Prospects // Plasma Processes and Polymers Volume 1, Issue 2. 2004

8. Kogelschatz, U. Dielectric-barrier Discharges: Their History, Discharge Physics, and Industrial Applications // Plasma Chem.and Plasma Proc., Vol. 23 No.1 2003.

9. Wagner, H.-E. Brandenburg, R. Kozlov K. V., et. al. The barrier discharge e: basic properties and applications to surface treatment // Vacuum 71, 2003. gads

10. Eliasson B., Hirth M., Kogelschatz U., Ozone synthesis from oxygen in dielectric barrier discharges // J. Phys. D: Appl. Phys. 20 1421-1437. 1987.

11. Kogelschatz U., Eliasson B., Hirth M.. Ozone Generation From Oxygen And Air: Discharge Physics And Reaction Mechanisms. Ozone sc. \& Engineering. 1988.

12. Intergovernmental panel on climate change http://www.ipcc.ch/publications_and_data/ar4/wg1/en/ch2s2-10-2.html [Accesed 27.08.2011]

13. Rafflenbeul, R. Non Thermal Plasma Plants: Experiences from the Industrial Praxis of Air Purification. International workshop "VOC and aerosol removal by means of plasma based and plasma assisted technologies" 2010

14. Cal, M.P. Schluep, M. Destruction of Benzene with Non-Thermal Plasma in Dielectric Barrier Discharge Reactors // Environmental Progress Vol 20, No. 32001.

15. Yu, D.Y. Kang, N. Bae W., et. Al.. Characteristics in oxidative degradation by ozone for satureted hydrocarbons in soil contaminated with diesel fuel // Chemosphere 66, 2007.

16. Kalisiak, S. Holub, M. Jakubowski, T. Resonant inverter with output voltage pulse-phase-shift control fot DBD plasma reactor supply // Power Electronics and Applications,. EPE '09. 13th European Conference. 2009.

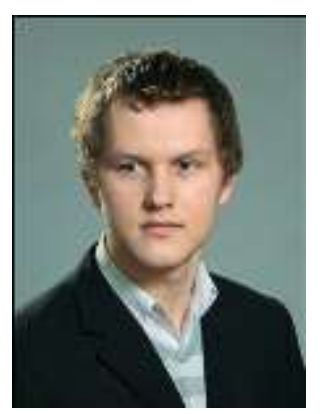

Janis Ikaunieks, Bc. Sc, senior laboratory assistant, Riga Technical university, Institute of Energy Systems and Environment. Since 2010 Janis Ikaunieks is working at Riga Technical University as a senior laboratory assistant. The main research area is renewable resources, energy efficiency, flue gas treatment, heating and plasma technologies. He has participated in PlasTEP project summer schools for two years in succession (2010, 2011). Janis Ikaunieks has Bachelor's Diploma in Environmental science. Bachelor thesis "Plasma technologies for flue gas treatment from VOC and $\mathrm{NO}_{\mathrm{x}}$ " was defended at the Faculty of Energy and Electronics, RTU in 2011. Since 2011, he continues his studies at the Master study program in Riga Technical university, Institute of Energy Systems and Environment. In 2011 for one 
month Janis Ikaunieks was a trainee at Leibniz Institute for Plasma Science and Technology, where the Bachelor's theses were developed.

Address: Kronvalda boulevard 1, LV-1010, Riga, Latvia

Phone: +371 67089943

E-mail: Janis.ikaunieks_1@rtu.lv

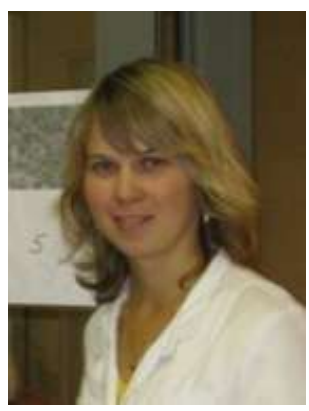

Liga Mezmale, Msc.ing., scientific assistant, Riga Technical University, Environmen Protection and Heating Systems Institute (2011). Scientific assistant Liga Mezmale has been part of scientific staff of Faculty of Materials science and applied Chemistry, Riga Technical University, Institute of General Chemical Engineering since 2007. The main research area is chemical engineering - sorption process for wastewater decontamination. She is author 9 Book of Abstracts. She has Master degree Chemical Engineering Diploma (2011) Mg.sc.ing. thesis "Study of porous carboxylic ion-exchangers structure and sorption properties". She is a member of: Latvian Materials Reseach Society and Association of Latvian Young Scientists.

E-mail: liga.mezmale@rtu.lv

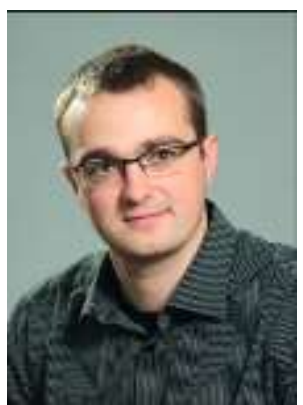

Aivars Zandeckis, M.sc., researcher, Riga Technical University, Institute of Energy Systems and Environment. Since 2005 Aivars Zandeckis is working in Riga Technical university as a head of Environmental monitoring laboratory and since 2010 as a researcher in Institute of Energy Systems and Environment. The main research areas are renewable energy resources and heating technologies. He has participated in 18 local and international scientific projects related to renewable energy use and efficiency improvement in residential, tertiary and commercial sectors. Aivars is an author of 19 scientific publications and coauthor of one monograph and two local patents. He has master Diploma in Environmental science. Master thesis "Research of pellet combustion efficiency" was defended in Faculty of Energy and Electronics, RTU in 2008. E-mail: aivars.zandeckis@rtu.lv

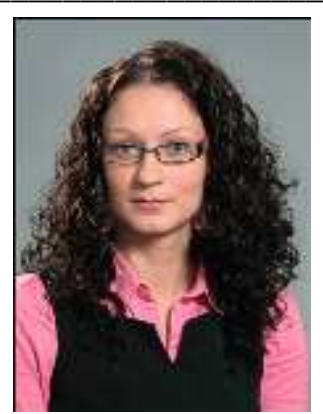

Jelena Pubule, M. sc., researcher. Jelena Pubule has been part of academic staff of Institute of Environmental Protection and Energy Systems, Faculty of Energy and Electrotechnics, Riga Technical University since 2008. Since 2010 she is $\mathrm{PhD}$ student. As a researcher, she has been involved in several energy and environmental research projects, in particular focusing on use of renewable energy sources and the environmental impact assessments connected with this topic. Her research interest includes environmental impact assessment, life cycle assessment and increase in the energy efficiency. She started her professional career as expert in environmental issues in LAKALME Ltd. in 2001-2008. It was followed by the career at the state environmental service as senior expert. She is author of 11 publications.

E-mail: jelena.pubule@rtu.lv

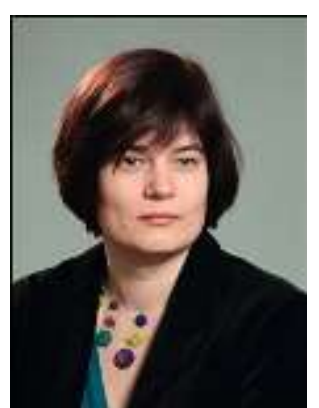

Andra Blumberga, Dr.sc.ing., professor has been part of academic staff of Institute of Environmental Protection and Energy Systems, Faculty of Energy and Electrotechnics, Riga Technical University since 2001. The main research area is end user energy efficiency. She started her professional career as energy auditor at Sloka pulp and paper factory in 1991-1993. It was followed by the six year employment as Manager of Ventilation and Refrigeration Dept. in ABB Latvia. From 1999-2008 Prof.Blumberga has been Director of Energy and Environmental Consulting at the company Ekodoma, where she is still acting as a consultant. She has participated in different local and international projects related to energy and environment, as well as is the author of many publications and books. She has Engineer and M.Sc. Diploma from Building Faculty, Riga Technical university and has her Ph.D. from Faculty of Energy , Riga Technical university (2001).

E-mail: andra.blumberga@ rtu.lv

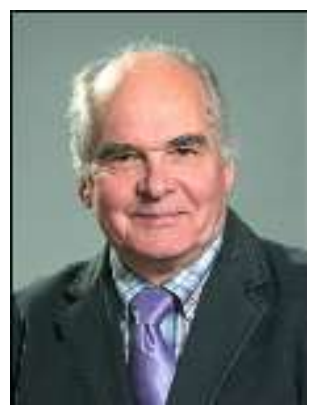

Ivars Veidenbergs, Dr.hab.sc.ing., Professor has been a part of academic staff of the Institute of Energy Systems and Environment, Faculty of Energy and Electrotechnics, Riga Technical University. He has thermal engineer diploma (1960) in speciality "Thermal equipment of thermal power stations" and two steps doctoral degree diploma. $\mathrm{PhD}$ thesis "Dynamic Temperature Regimes of Thermoelectric Cooling Devices" was defended in Riga Polytechnic Institute (1975). Doctor Habilitus Thesis "Engineering Methods for Calculating Hear and Mass Transfer in the devices of Power Units" was defended in Faculty of Energy and Electronics, Riga Technical University (1992). The main research area is energy and environment. He is the author of more than 180 publications and 5 books.

E-mail: ivars.veidenbergs@rtu.lv

Jānis Ikaunieks, Līga Mežmale, Aivars Žandeckis, Jelena Pubule, Andra Blumberga, Ivars Veidenbergs. Zemas temperatūras plazma GOS attīrīšanai dūmgāzēs.

Šĩ darba galvenais mērḳis bija veikt izpēti zemas temperatūras plazmas lietojumam dūmgāzu attīrīšanā no gaistošajiem organiskajiem savienojumiem (GOS). GOS tiek minēti kā prekursori - vielas, kas veicina piezemes ozona veidošanos, noārda stratosfēras ozona slāni un uzkrājas apkārtējā vidē, kā arī piedalās fotoḳīmiskās reakcijās, veido toksiskus un kancerogēnus savienojumus. Tiek uzskatīts, ka zemas temperatūras plazmas tehnologijas nākotnē varētu samazināt emisijas l̦oti efektīvi un par saprātīgām izmaksām. Plazma gaisā veido ozonu, kas ir viens no labākajiem oksidētājiem, ar kuru ir iespējams attīî̀t GOS līdz $\mathrm{CO}_{2}$ un ūdenim, tāpēc tika apskatītas GOS attīir̄̌šanas iespējas ar plazmu. Tika pētīti galvenie procesi, kas norisinās plazmā. Eksperimentālais stends tika izveidots INP institūtā Greifsvaldē Vācijā. Pētījumāe, analizējot plazmas reaktora darbību un ozona veidošanos, tika konstatêts, ka ozona veidošanās procesā slāpekla oksīdu formēšanās gāzu sastāviem ar un bez GOS bija atškirīga. Tika noteikts, ka plazmā veidojas ne tikai $\mathrm{CO}_{2}$ un $\mathrm{H}_{2} \mathrm{O}$, bet arī daudz dažādi blakusprodukti. Kā galvenos var minēt $\mathrm{N}_{2} \mathrm{O}$ un skudrskābi. Nepiln̄̄gi oksidējoties rodas arī citi GOS, tomēr izmantojot FTIR spektrometru, to nebija iespējams noteikt, jo notika spektru pārklāšanās. Tika sasniegta 27 \% GOS attīrī̌sanas efektivitāte un piedāvāti risinājumi, kā palielināt šo efektivitāti, nepalielinot reaktora jaudu. Citu GOS veidošanās apstākḷu izpētei, kā arī attīrī̌anas efektivitātes paaugstināšanai, ir nepieciešami plašāki eksperimentāli pētījumi. 